\title{
Advantages of emergence method, modified for laboratory conditions, for the investigation of soil Diptera (Insecta)
}

\author{
Преимущества эмергенщ-метода, модифищированного Аля \\ мабораторных условий, для изучения почвенных двукрылых \\ (Insecta: Diptera)
}

\author{
M.G. Krivosheina \\ М.Г. Кривошеина
}

\begin{abstract}
A.N. Severtsov Institute of Ecology and Evolution, Russian Academy of Sciences, Moscow, 119071 Russia. E-mail: dipteramarina@rambler.ru

Институт проблем экологии и эволюции им. А.Н. Северцова РАН, Ленинский проспект, 33, Москва, 119071 Россия. E-mail: dipteramarina@rambler.ru
\end{abstract}

KEY WORDS: Diptera, soil, larva, imago, emergence method, laboratory modification, Vorob’evy Gory Nature Park.

КЛЮЧЕВЫЕ СЛОВА: двукрылые, почвенный, личинка, имаго, эмергенц метод, лабораторная модификация, природный парк «Воробьевы Горы».

ABSTRACT: Emergence-method, modified for laboratory conditions, is proposed for the investigation of soil Diptera. The method was tested using soil samples from Vorob'evy Gory Nature Park, Moscow. The number of determined Diptera species determined as imagoes increased several times in comparison with those determined from larvae. It was shown that at least 17 species of Diptera are capable to develop to the stage of imago in highly polluted technosols.

РЕЗЮМЕ: Для изучения почвенных двукрылых насекомых в работе предложена лабораторная модификация эмергенц-метода. Метод был опробован на двукрылых природного парка «Воробьевы Горы», Москва. В результате количество двукрылых, определенных до вида по имагинальной стадии, оказалось в несколько раз больше, чем при проведении аналогичных работ с использованием только личинок. Было выявлено, что 17 видов двукрылых насекомых способны жить и развиваться до стадии имаго в сильно загрязненных техногенных почвах.

\section{Introduction}

Many methods for collecting and investigation of soil invertebrates were worked out during a period of more than 100 years and are applied successfully one at a time or in some combinations depending on the problem arised by the researcher. More common of them used by entomologists are collecting or catching insects in nature with the help of sweeping net, exhauster or some other devices; using pitfall traps and ditches with further taking insects out of them periodically [Bramson, 1896, Tikhomirova, 1975]; using emergence traps in nature; taking out soil substrates of certain volume and from certain depth [Morris, 1922] for the further extracting insects from them with the help of aquaticdevice [Grigorieva, 1938], system of sieves [Balogh, 1958], thermoextractors, hand sorting etc. [Ghilarov, 1975]. All these methods satisfactory for collecting different invertebrate animals and used for diverse purposes sometimes are not enough for the realistic evaluation of the soil Diptera fauna composition.

\section{Material and methods}

Many of the abovementioned methods are not good for Diptera larvae because these larvae are small, majority of them have tiny soft cuticle - the larvae are dried out and perish or cracked by soil particles during such manipulations and don't reach the investigator. Besides using hand sorting you get usually larvae of medium length $(0.5-6 \mathrm{~cm})$ with solid cuticle (Rhagionidae, Tabanidae, some Limoniidae etc., Fig. 2) and after sorting with termoextractor - Cecidomyiidae and some other groups. Moreover the determination keys for soil larva of Diptera are not worked out enough to determine them to species and this cause additional difficulties even in case when you manage to extract many larvae for scientific research.

As a rule emergence method with placing emergence trap in nature above soil substrate allows us to avoid some of these difficulties. As a result we get emerged imagoes of Diptera from such trap. It is much 


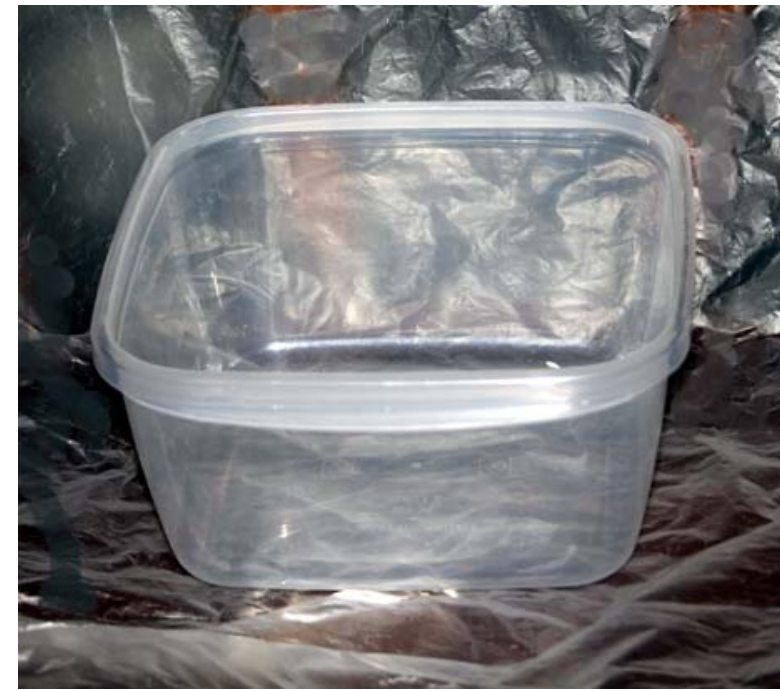

Fig. 1. Plastic container $15 \times 15 \times 10 \mathrm{~cm}$ for soil sample.

Рис. 1. Пластиковый контейнер $15 \times 15 \times 10$ см для почвенной пробы.

easier to determine imago to species, than larvae. However you can not guarantee that all collected Diptera developed in soil. You are to take into consideration some accidental penetrations of other groups of Diptera inside such trap which may happen.

So we decided to think of some perfect rearing method for soil Diptera. It is as follows: you take certain volume of soil which you would like to investigate and place it inside opened container (Fig. 1). The number of samples depends on your own aims. The container is put inside halftransparent large white package, with the volume about 20-30 1, which is tied and completely closed at the top. Then you are to keep such packages with the substare in the laboratory and to check them from time to time, collecting emerged imagoes of flies. It is recommended to moisten the substrate 1-2 times a week in such a way that the soil was not dry. This method can be divided in several subdivisions depending on your concrete aims.

1) If you want to get some data on hibernating insects, then the best time of starting such experiment in the end of winter at the time when the blanket of snow is disappearing. At this case you will get the majority of hibernated insects during rather short time in the nearest month.

2) Spring is very good time too, for up to this time many emerged insects have laid eggs, but in this case the time of checking the samples is much longer imagoes of some species may appear at summer or autumn, moreover larvae of some univoltine species may live in such sample till next spring.

3) For some special purposes it may be some other season.

During soil zoological studies the samples are usually taken at some short seasonal interval (as a rule in spring or in summer). As a result different investigators can get different composition of Diptera from the same soils. The matter is that the life cycle of soil Diptera is

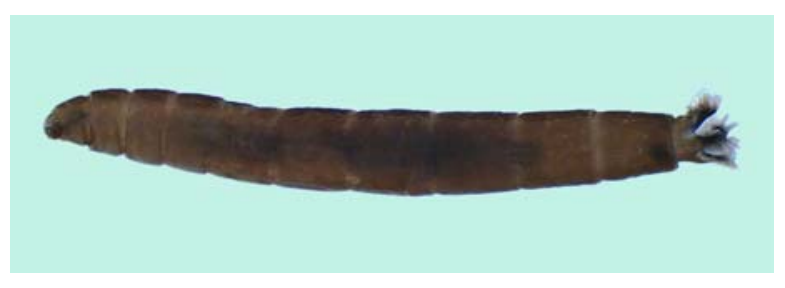
1838 .

Fig. 2. Larva of Rhypholophus haemorrhoidalis Zetterstedt,

Рис. 2. Личинка Rhypholophus haemorrhoidalis Zetterstedt, 1838

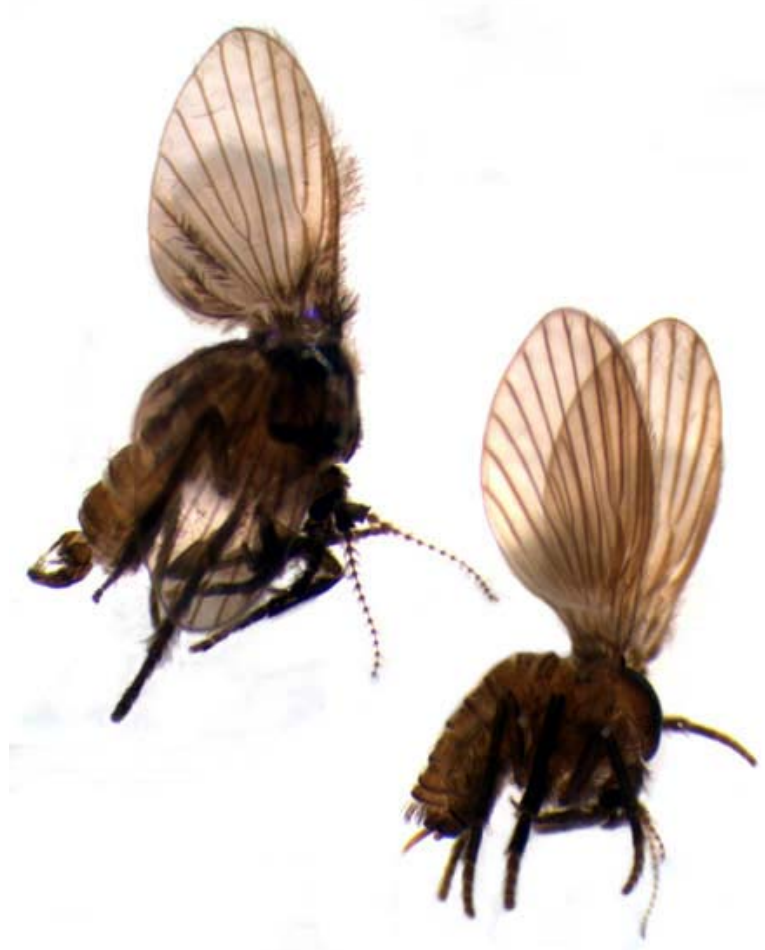

Fig. 3. Imago of Peripsychoda auriculata (Curtis, 1839).

Рис. 3. Имаго Peripsychoda auriculata (Curtis, 1839).

very different according to its duration and the stage of larval development depends of weather, humidity, temperature and other conditions. If the aim of the work is to give some quality characteristic of the soil it would be better first, to use whole-year monitoring to get the majority of species of insects and second to evaluate those species who managed to complete their life-cycle to imaginal stage (Fig. 3). In the case of some strongly polluted soils some species may perish not reaching imaginal stage. If so, then the compound of species determined from larval stage can not reflect the real quality of the soil.

We checked the packages 2 times a week or when we noticed some flying imago inside it with help of exhauster. Imago were fixed in $70 \%$ alhogol or pinned, the label with necessary data made. We tested this method for soil Diptera from Vorob'evy Gory Nature Park in Moscow and were satisfied with the results. 
Table. Species composition of soil Diptera of Vorob'evy Gory Nature Park. Таблица. Видовой состав почвенных двукрылых насекомых природного парка «Воробьевы горы».

\begin{tabular}{|c|c|c|c|c|}
\hline No. & Species name & Family & $\begin{array}{l}\text { Discovered } \\
\text { stage of } \\
\text { development }\end{array}$ & Distribution \\
\hline 1. & $\begin{array}{l}\text { Limnophila (Limnophila) pictipennis } \\
\text { (Meigen, } 1818 \text { ) }\end{array}$ & \multirow{5}{*}{ Limoniidae } & i, $1 \mathrm{f}$ & (PA: PA) Europe \\
\hline 2. & Ilisia maculata (Meigen, 1804) & & $\mathrm{i}, 3 \mathrm{~m}, 2 \mathrm{f}$ & (PA: PA) Europe \\
\hline 3. & $\begin{array}{l}\text { Neolimnomyia (Brachylimnophila) } \\
\text { nemoralis (Meigen, 1818) }\end{array}$ & & $\mathrm{i}, 1 \mathrm{~m}$ & (PA: PA) Europe \\
\hline 4. & $\begin{array}{l}\text { Paradelphomyia (Oxyrhiza) senilis } \\
\text { (Haliday, 1833) }\end{array}$ & & $\mathrm{i}, 3 \mathrm{~m}, 2 \mathrm{f}$ & (PA: PA) Europe \\
\hline 5. & $\begin{array}{l}\text { Rhypholophus haemorrhoidalis } \\
\text { Zetterstedt, } 1838\end{array}$ & & 101 & (PA) \\
\hline 6. & Tipula (Acutipula) maxima Poda, 1761 & Tipulidae & $21, \mathrm{i}, 1 \mathrm{~m}$ & $\begin{array}{c}\text { (PA: PA) Europe: North Africa: } \\
\text { ?Algeria }\end{array}$ \\
\hline 7. & Peripsychoda auriculata (Curtis, 1839) & Psychodidae & $\mathrm{i}, 5 \mathrm{~m}, 4 \mathrm{f}$ & (PA: PA) Europe \\
\hline 8. & Palpomyia $\mathrm{sp.}$ & $\begin{array}{l}\text { Ceratopogo- } \\
\text { nidae }\end{array}$ & $\mathrm{i}, 2 \mathrm{f}$ & Moscow \\
\hline 9. & Odontomyia ornata (Meigen, 1822) & Stratiomyiidae & 11 & $\begin{array}{l}\text { (PA: PA) Europe, Asia } \\
\text { (Kazakhstan) }\end{array}$ \\
\hline 10. & $\begin{array}{l}\text { Rhaphium appendiculatum Zetterstedt, } \\
1849\end{array}$ & \multirow{4}{*}{ Dolichopodidae } & $\mathrm{i}, 1 \mathrm{~m}, 1 \mathrm{f}$ & (PA) \\
\hline 11. & Syntormon fuscipes (von Roser, 1840) & & $\mathrm{i}, 1 \mathrm{~m}, 1 \mathrm{f}$ & $\begin{array}{l}\text { (PA: PA) Europe: Carpathians, } \\
\text { Russia: North Caucasus, Africa: } \\
\text { Kenya, Burundi. }\end{array}$ \\
\hline 12. & Gymnopternus sp. & & i, $1 \mathrm{f}$ & Moscow \\
\hline 13. & Hercostomus sp. & & i, $1 \mathrm{f}$ & Moscow \\
\hline 14. & Lyciella laeta (Zetterstedt, 1838) & Lauxaniidae & i, $1 \mathrm{f}$ & (PA: PA) Europe: Russia \\
\hline 15. & Dilophus sp. & Bibionidae & $\mathrm{i}, 1 \mathrm{f}$ & Moscow \\
\hline 16. & Sciaridae gen.sp. & Sciaridae & i, $1 \mathrm{f}$ & Moscow \\
\hline 17. & Cecidomyiidae gen.sp. & Cecidomyiidae & i, $1 \mathrm{f}$ & Moscow \\
\hline
\end{tabular}

Abbreviations: $\mathrm{f}$ - female(s), i - imago, 1 - larva(e), m - male(s).

\section{Description of the investigated territory}

The Vorob'evy Gory Nature Park, the area of which is about 145 ha, was established by the Moscow Government in 1998 for the purpose of conservation and restoration of the city nature complex. This territory is characterized by a landscape with unique combination of soil-forming factors and the relief. The flora of the territory is represented by such trees as Quercus robur, Tilia cordata, Acer platanoides, Betula pendula, Fraxinus excelsior, there are different species and forms of Syringa, Spiraea, Lonicera, Euonymus verrucosus among shrubs, the herbaceous are like Gagea, Convallaria, Anemone, Veronica, Potentilla, Ranunculus and others.

Steep and extended slopes of $f$ the Terplostanskaya upland in the Moscow River valley with relative drop in elevation about $70 \mathrm{~m}$, surface steepness $15-35^{\circ}$, maximal $50-60^{\circ}$, determine absolute dominance of surface flow over vertical migration of soil water. As a result the main natural soil processes are the humusforming soil-process, the formation of sod-layer as well as satellite processes - gleization and erosion [Paramonova et al., 2010]. On the whole the natural soil cover of Vorobi'evy Gory theoretically must be repre- sented by sod-podzol soils of bear-slope parts of watershed, sod soils of slopes with sod-gley soils of foots and releief depressions and also with alluvial soils of the Moscow River floodplain. For the territory is situated inside such large megapolis as Moscow, the relief of the territory was specifically transformed during the construction of the subway, making some further improvements to the territory. As a result of the polluted natural-anthropogenic and anthropogenis soils occupy in total $90 \%$ of the area of soil cover. Their cheminal properties show that the features of urban forest-park soils resemble technosols more than natural soddypodzolic soils. Generally soils of Vorob'evy Gory Nature park are characterized with high content of technogenic ecotoxicants - benzopyrene, heavy metals and mineral oils [Tishkina et al., 2010].

\section{Discussion}

The idea of this work was: first, to discover the complex of Diptera larvae inhabiting technosols and capable to reach the stage of imago; second, to test the new modification of emergence method and discover its advantages or disadvantages for investigation of soil Diptera. 
The experiment was started at the end of April 2009 , when the soil was partly covered with snow and was characterized with too low temperature for emerging of insects. Nine samples $15 \times 15 \times 10$ were taken and put inside plastic containers placed inside hemitransparant thin 30-litre packages. Three samples were hand-sorted, the larvae were fixed in $70 \%$ alhogol. Extracting of emerged insects was made during MayJune 2009. As a result we discovered 17 species of Diptera (Table), which are capable to inhabit and develop to the stage of imago in highly polluted technosols.

\section{Conclusions}

The advantages of the proposed modification of emergence method are as follows.

1) The soil sample, taken and put under laboratory conditions, with further rearing and fixation of emerging insects, allows us to be sure that we have a deal with soil insects only.

2) This way of taking sample with further placing inside plastic box allows us to avoid cracking and damaging of Diptera larvae.

3) The method can be used in combination with thermoextractor, hand-sorting and other methods.

4) As a result of this method we get imaginal stages of Diptera, which are much easier to be determined in comparison with larvae. So we can operate with majority of specimens determined to species, not to family, as it was traditionally accepted for soil-zoological studies.

5) This modification of emergence-method may be more productive and effective for the investigation of soil Diptera and allows to discover more species and taxa.

6) This method allows to make conclusions about the quality of the soil basing on insects reaching imagi- nal stage, for many species perish in polluted soils at larval stage.

\section{ACKNOWLEDGEMENTS}

I wish to express my sincere gratitude to my colleagues who helped me to determine the materials on imagoes and larvae of soil Diptera: D.I. Gavryushin (Zoological Museum Moscow University), I.J. Grichanov (All-Russia Institute of Plant Protection, St.-Petersburg), A.I. Shatalkin (Zoological Museum Moscow University), Phil Withers (Lyon, France), Ton van Haaren (Amsterdam, Netherlands). I am grateful to A.Z. Barne (Institute of Ecology and Evolution, Moscow) for the help in collecting soil samples.

\section{References}

Balogh J. 1958. Lebensgemeinschaften der Landtiere. BudapestBerlin: Akademie-Verlag. $560 \mathrm{~S}$.

Bramson K.L. 1896. [Insect pests and means of struggle agaist them (practical entomology)]. 2nd edition. Ekaterinoslav. Vol.2. 360 p. [in Russian]

Ghilarov M.S. (ed.) 1975. [Methods of soil zoological studies]. Moscow: Nauka. 280 p. [in Russian]

Grigorieva T.G. 1937. [To the method of the census of the soil fauna] // Zashita Rastenij. No.17. P.97-110 [in Russian].

Morris H.M. 1922. On a method of separating insects and other Arthropods from the Soil // Bull. Entomol. Res. Vol.13. P.197200 .

Paramonova T.A., Tishkina E.V., Krasnov S.F., Tolstikhin D.O. 2010. Soil Cover Structure and main Soil Properties of the Vorob'evy Gory Nature Park // Moscow University Soil Bulletin. Vol.65. No.1. P.22-31.

Tikhomirova A.L. 1975. [Taking censuses of soil surface dwelling invertebrates] // Metody pochvennoi zoologii. Moscow: Nauka. P.73-85 [in Russian].

Tishkina E.V., Paramonova T.A., Krasnov S.F., Tolstikhin D.O. 2010. Estimation of Soil Pollution by the Main Ecotoxicants in the Vorob'evy Gory Nature Park // Moscow University Soil Bulletin. Vol.65. No.1. P.39-45. 